\title{
Impact of the Salespeople's Personality Traits and Relationship-Oriented Behavior on Customer Loyalty Case Study: Life and Savings Insurance
}

Javad Mehrabi ${ }^{1}$ Assistant Professor Department of Public Administration, Qazvin Branch, Islamic Azad University, Qazvin, Iran.

Mahdi Zakipour ${ }^{2}$ Assistant Professor Department of Business Administration, Qazvin Branch, Islamic Azad University, Qazvin, Iran. (Corresponding Author)

Received: 09/11/2019 | Accepted: 06/03/2021

\begin{abstract}
Purpose: This research intends to investigate the effects of the salespeople's characteristics and the seller-customer interaction on the quality of interactive relations and loyalty among the customers of the insurance industry.

Methodology: Statistical population consisted of Karaj Branch of the Iranian Insurance Corporation custumers. Applying cluster random sampling technique, 253 questionnairs were distributed. In order to analyze the data, structural equation modeling was used.

Findings: Results of hypotheses testing show that the customer's personality traits has positive and significant effect on the relationship between customer and seller. Communicative selling behavior and the quality of the relationship affects customer loyalty positively and significantly. Besides, the mediating role of customer relationship quality has positive and significant effect on the relation between salespeople's personality traits and customer loyalty.

Originality/ Value: Compared to other relevant studies, the present research has focused on the variables affecting relationship quality and customer loyalty at the same time. Moreover, the two variables of percieved price and customer's willingness for relationship are emphasized as mediators in the interaction between salespeople's personality traits and communicative selling behavior and the quality of relationship with customers, which are significant. With regards to the nature of the insurance industry services, these findings can be utilized by isurance companies.
\end{abstract}

Keywords: Salespeople's Personality Traits, Communicative Selling Behavior, Quality of Relationship with Customer, Perceived Price, Customer's Willingness for Relationship, Customer Loyalty.

1.mehrabijavad@qiau.ac.ir

2.m.zakipour@qiau.ac.ir 
عنوان مقاله: تاثير خصوصيات فروشنده و رفتار رابطهمند بر وفادارى مشتريان (مورد مطالعه: بيمهدهاى

عمر و يسانداز)

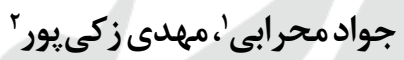

مقاله بزوهشى

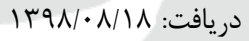

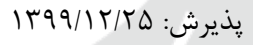

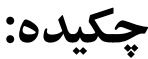

هدف: هدف يزوهش حاضر بررسى تاثير ويثَّى هاى فروشنده و تعاملات بين فروشنده ـ

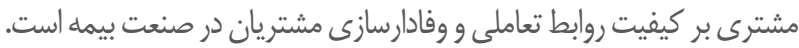

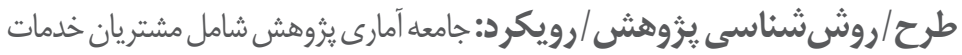

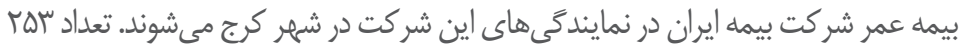

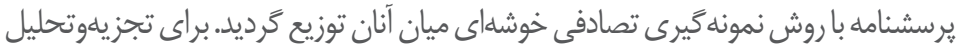

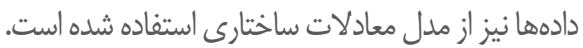

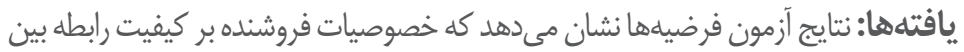

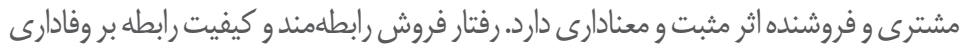

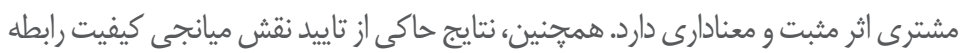

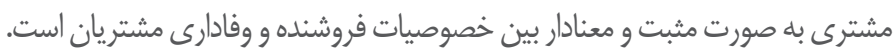

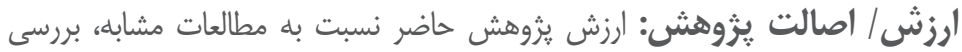

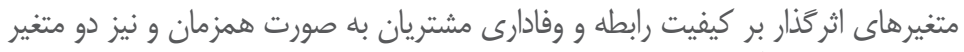

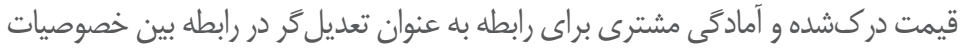

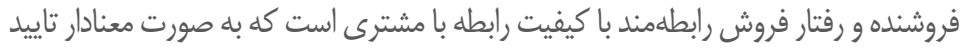

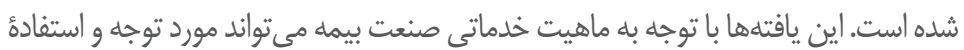
شركتهاى بيمه قرار گيرد.

كليدوازهها: خصو صيات فروشنده، رفتار فروش رابطهمند، كيفيت

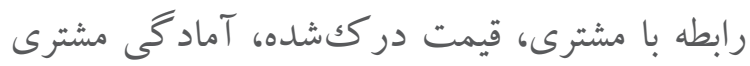

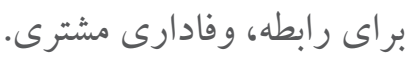

mehrabijavad@qiau.ac.ir

1. استاديار گرووه مديريت دولتى، واحد قزوين، دانشكاه آزاد اسلامى، قزوين، ايران. r. استاديار گروه مديريت بازر كانى، واحد قزوين، دانشخاه آزاد اسلامى، قزوين، ايران (نويسنده مسئول). m.zakipour@qiau.ac.ir 


\section{مقام}

افزايش رقابت، يويايى و يِيجيده شدن محيط، يررنگ شدن بخش خصوصى، رشد انتظارات

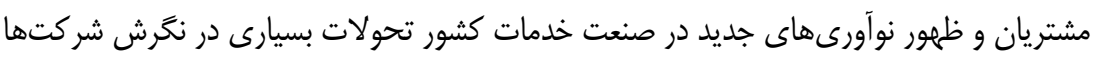

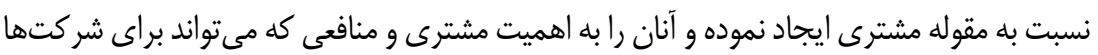
به دنبال داشته باشد، واقف نموده است (Ansari \& Riasi, 2016). مشتريان وفادار در صنعت بيمه مزاياى بسيارى ازجمله سودآورى شركتهاى بيمه، كاهش هزينههاى بازاريابى، افزايش فروش

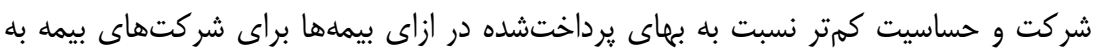

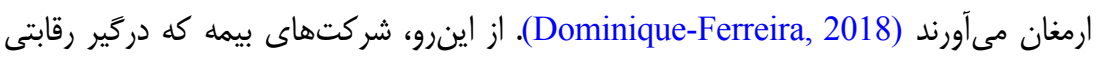
سخت در ميان مشتريانى مشكليسند با حق انتخاب بالا هستند، نياز به شناختن علل و عواملى

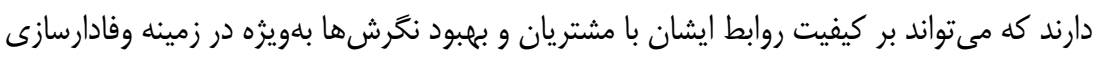
ايشان نسبت به سازمان و خدمات آن اثركذار باشد.

در اين يزوهش، خصوصيات فروشنده اثركذار بر كيفيت روابط در قالب سه خصيصه تبحر،

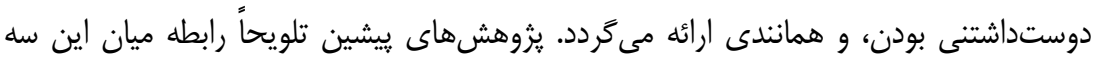
متغير و كيفيت روابط را نشان دادهاند (Chen et al., 2008; Lee et al., 2009). همجنين، رفتارهاى فروش رابطهمند در اين مطالعه در قالب سه متغير تسهيم اطلاعات، افشاسازى دوطرفه، و كثرت تعاملات ارائه مى در زمينه تقويت كيفيت روابط داشتهاند (Tai et al., 2010; Ndubisi, 2007). همجنين، در اين مطالعه كيفيت رابطه نيز در قالب سه متغير رضايت، اعتماد، و تعهد ارائه مى اطمينان هرجه بيشترى در زمينه يوشش ابعاد مختلف متغيرهاى خصوصيات فروشنده، رفتار فروش رابطهمند، و كيفيت رابطه مشترى بهدست آيد.

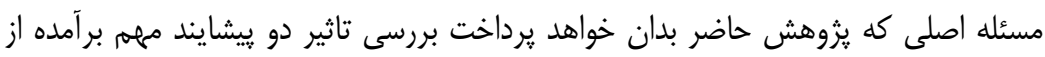

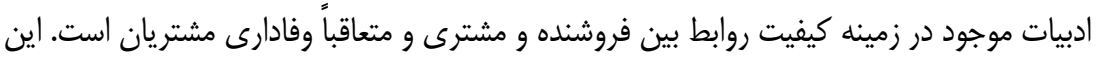
دو ييشايند يا دو عامل تعيين كننده، ويثگى هاى فروشنده و تعاملات رفتارى بين فروشنده و مشترى

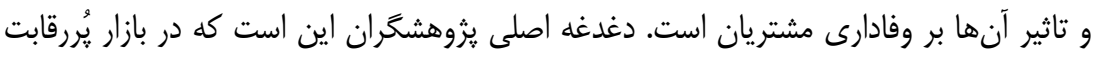
صنعت بيمه كه مشتريان حق انتخاب بالايى در خصوص شركت بيملكننده دارند، نشان دهند 
كه توانمندىهاى فنى و رفتارى فروشندًان و رفتارهاى تعاملى فروشندكان با مشتريان קֶحونه

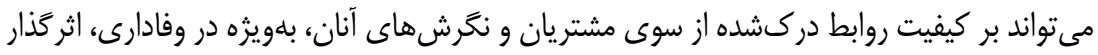

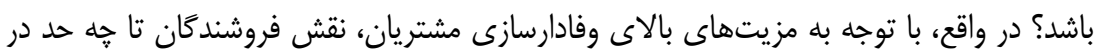
اين زمينه حياتى است؟ ونقش كيفيت روابط دركشده از سوى مشترى در زمينه سوق دادن وى بان

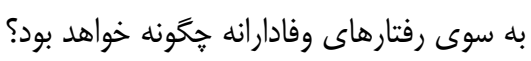

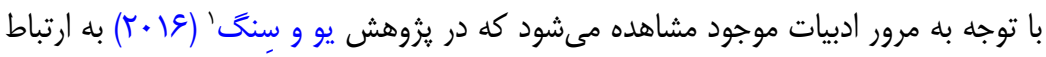

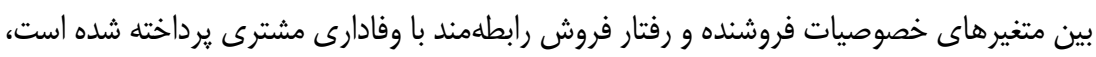

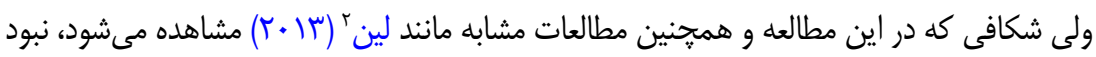

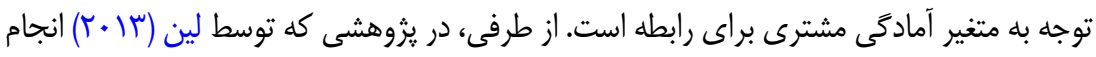

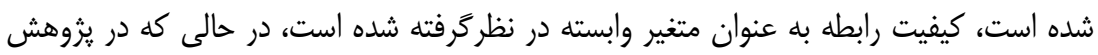
حاضر اين متغير بنابر ادبيات (Gharepasha et al., 2018; Choi \& Hyun, 2017) به عنوان

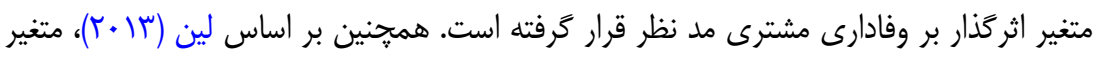

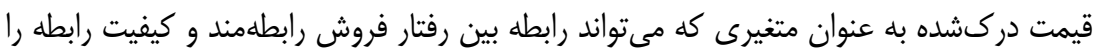

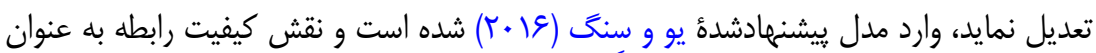
متغيرى كه خصوصيات فروشنده و رفتار فروش رابطهمند و وفادارى مشترى را ميانجى گرى مى كند نيز مورد بررسى قرار كرفته است.

\section{مبانى نظرى ثئوهش، ايجاد و توسعة فرضيهها}

\section{خصوصيات فروشنده و كيفيت رابطه}

مهارت و خبركى يك فروشنده عموماً توسط دانش، قابليتهاى فنى و توانمندى او به

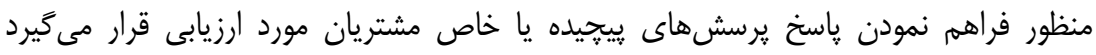

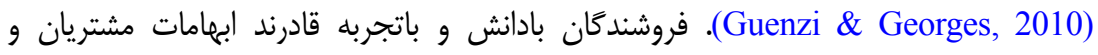
احساسات نامطلوب را در زمينه آسيبيذير بودن كاهش دهند (Guenzi \& Georges, 2010). سطح و ميزان تخصص و جيرگى موجود در يك فروشنده كه مبتنى بر دانش، تجربه يا مهارتهاى نهاى

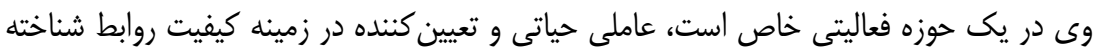

1. Yu \& Tseng

2. Lin 
مىشود. يى و همكاران' (1) (1)، نشان مىدهند كه دوستانه بودن رفتار يكى از مهمترين ويثگى ها

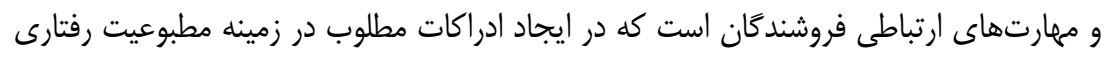

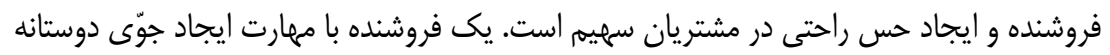

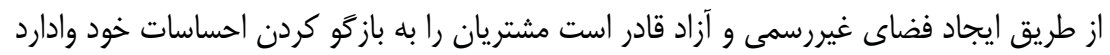

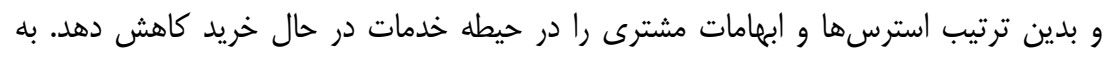

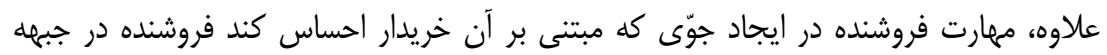

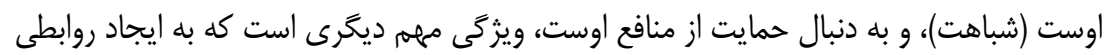

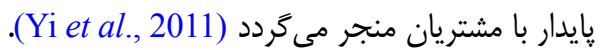

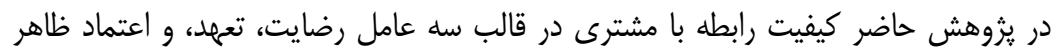

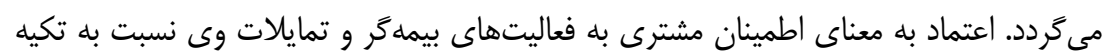
بر رفتارها و ييشنهادهاى بيمهكَ است. رضايت به ميزان خرسندى مشترى از سختافزارهان

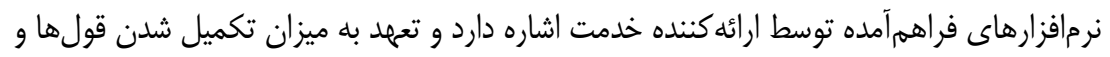

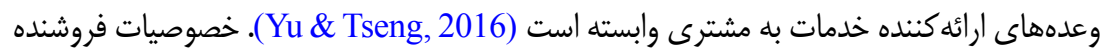
در يزوهش حاضر در قالب سه متغير تبحر، دوستداشتنى بودن، و همانندى ارائه مى كردد. تبحر

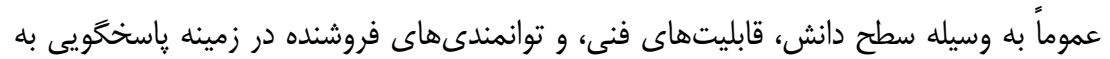

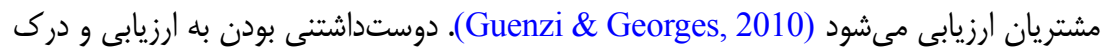
فرد از ميزان دوستانه بودن رفتار، ادب و تواضع، و خوشايند بودن رفتارهاى طرف مقابل اشاره دارد

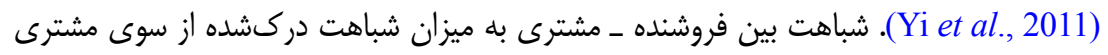

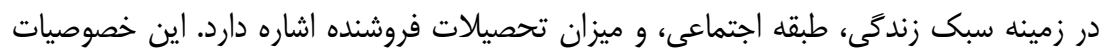

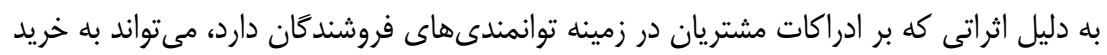

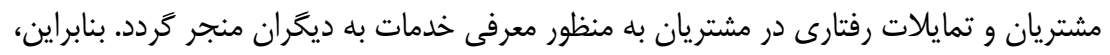

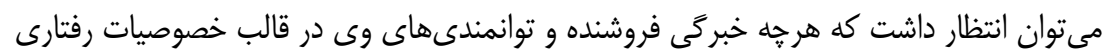

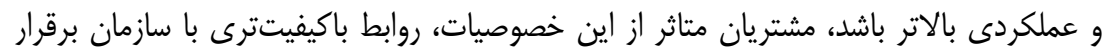

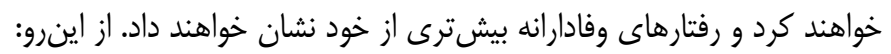

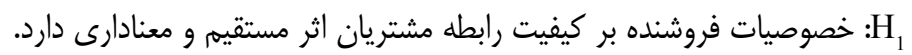
H: خصوصيات فروشنده بر وفادارى مشتريان اثر مستقيم و معنادارى دارد.

1. Yi et al. 


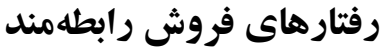

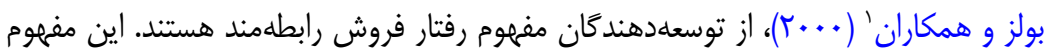
دربردارنده فعاليتهايى همجون به اشتراكگذارى اطلاعات، افشاسازى متقابل، تعاملات بالا و ونان

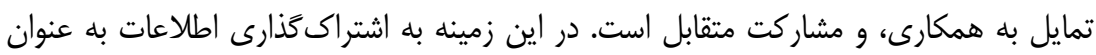
اساسىترين بخش در زمينه ايجاد و توسعه اعتماد به رابطه و رضايت از رابطه در نظرًّرفته مى دشود

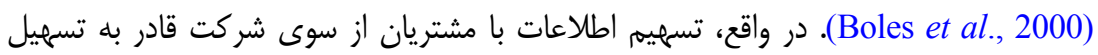

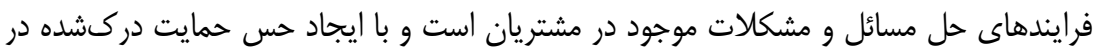
مشتريان به تقويت تمايل به توسعه روابط در ايشان منجر مىشود. به علاوه، به اشتراك كذارى

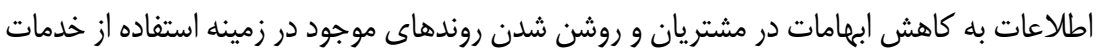

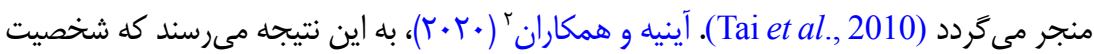

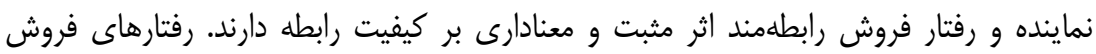

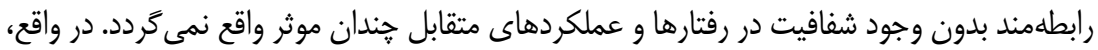
مشتريان با مشاهده شفافيت عملكردى شركتها و معين بودن تمامى فرايندها و مراحل خود نيز

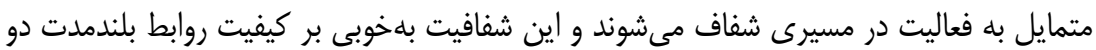
طرف اثركذار است (Ndubisi, 2007). در يزوهش حاضر اين مفهوم بر مبناى سه عامل تسهيميم

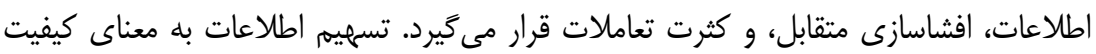
(دقت، تماميت، قابليت اعتماد، و مناسبت) و محتواى اطلاعات ردوبدلشاندات بين فروشنده و مشترى است (Li \& Lin, 2006). افشاسازى متقابل به ميزان اطلاعات حساس و مهم فراهمشده براى

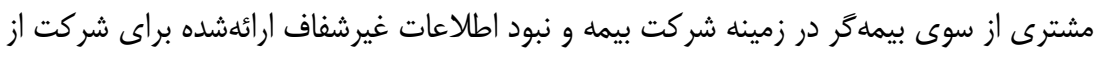

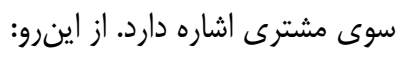
H: رفتار فروش رابطهمند بر كيفيت رابطه مشتريان اثر مستقيه و معنادارى دارد.

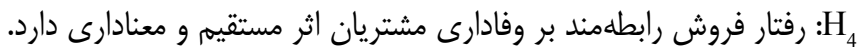

وفادارى مشترى

در ديدكاه امروزى، وظيفه بازاريابى شامل رشد دادن مشترى، يعنى توجه به رضايتمندى و

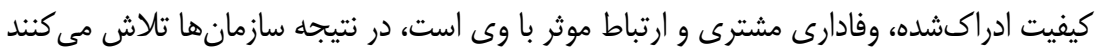

1. Boles et al.

2. Ainiyah et al. 


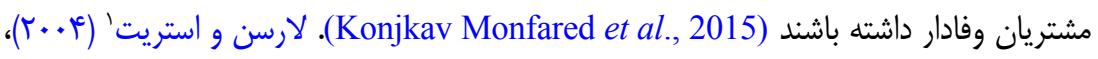

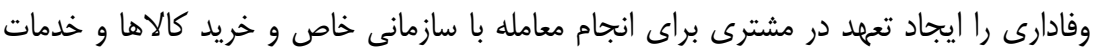

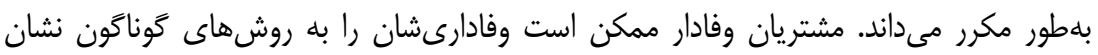

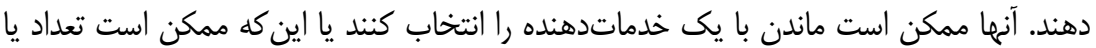

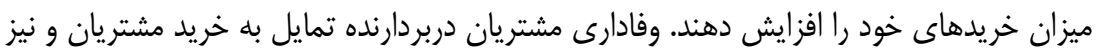

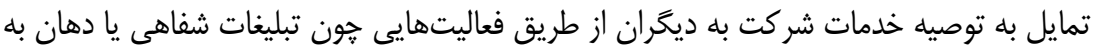

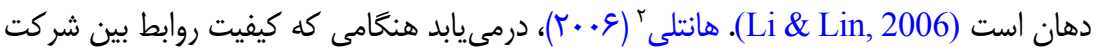

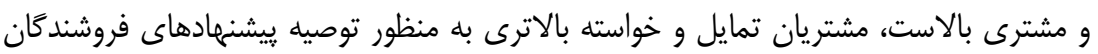

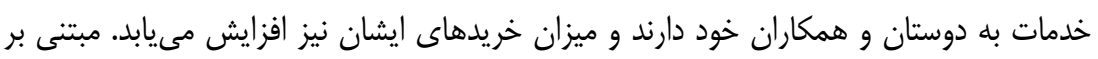

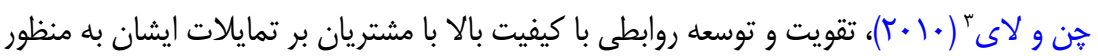

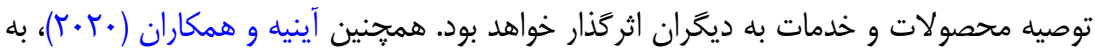

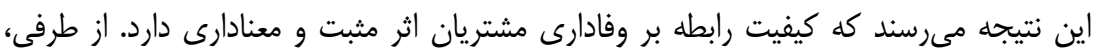

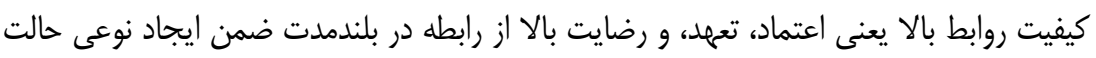

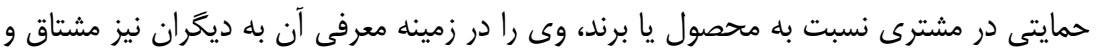

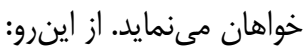
Hيفيت رابطه مشترى با سازمان بر وفادارى مشتريان اثر مستقيه و معنادارى دارد.

\section{آمادكى مشترى براى رابطه}

آمادگى مشترى به شرايط يا وضعيتى كه مصرف كننده در آن آماده است و احتمالاً براى اولين بار از يك خدمت يا نوآورى استفاده مى كند اطلاق مى شود (Poushneh \& Vasquez-Parraga, 2019). اين مفهوم به نكرشهاى مشتريان در زمينه تمايل به برقرارى و توسعه روابط با تامين كننده خدمت

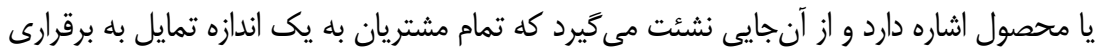

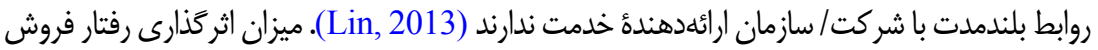

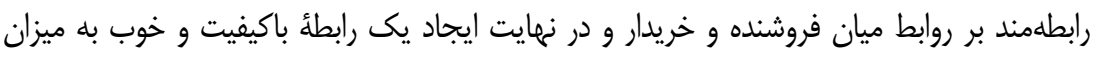
زيادى تحت تاثير انتظاراتى است كه مشتريان از نقشهاى رفتارى فروشندكان دارند

1. Larson \& Street

2. Huntley

3. Chen \& Lai 


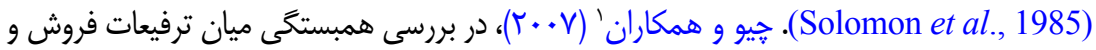

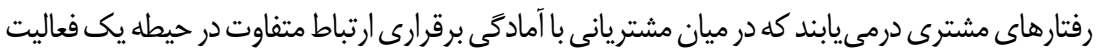

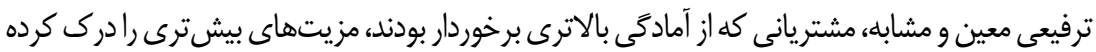

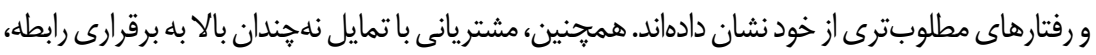

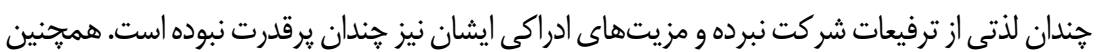

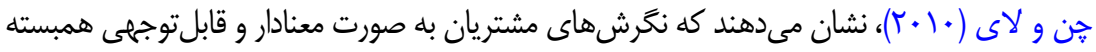

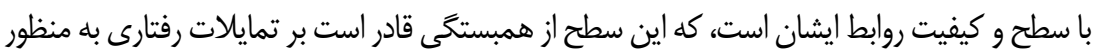
افزايش خريد از شركت اثركذار باشد. از اينرو: خص خصوصيات فروشنده و كيفيت رابطه مشتريان دارد.

\section{قيمت در ككشده}

اين مفهوم به ادراكها و برداشتهاى ذهنى مشتريان در زمينه سطح قيمت خدمات و محصولات اشاره دارد. قيمت به عنوان يكى از نشانههاى خارجى از مهمترين ابزارهاى در دست دان دان مشتريان به منظور ارزيابى و قضاوت در زمينه كيفيت محصولات و خدمات است (Lin, 2013).

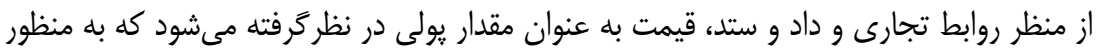
كسب و بهدست آوردن محصول يا خدمتى خاص هزينه مى گردد. هرجه سطح برداختى بالاتر باشد، تقاضاى ايشان براى دريافت خدمت يا محصول بالاتر افزايش مىيابد و به صورت

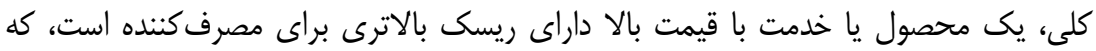
اشاره به ريسك فرصت از دسترفته دارد (Chen et al., 2007). بنابراين، هنكامى كه مشتريان محصول يا خدمتى را با قيمت بالا خريدارى مى كنند، اين اميد را دارند كه كاركنان ارائه كننده

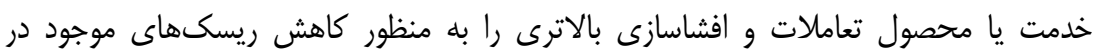

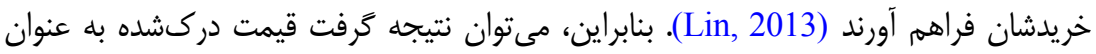

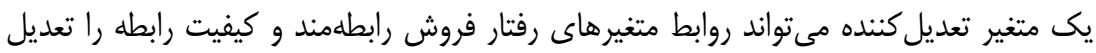

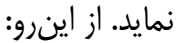
قيمت دركشده از سوى مشترى، نقش تعديل كننده مستقيم و معنادارى در رابطه بين رفتار فروش رابطهمند و كيفيت رابطه مشتريان دارد.

1. Chiu et al. 


\section{كيفيت رابطه و وفادارى مشترى}

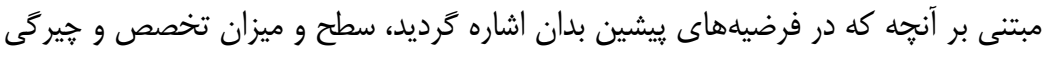
موجود در يك فروشنده كه مبتنى بر دانش، تجربه يا مهارتهاى وى در در يكى حوزه فعاليتى

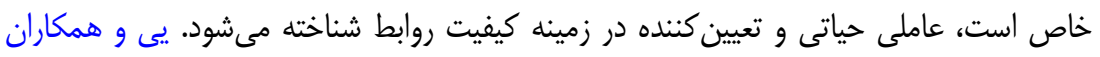

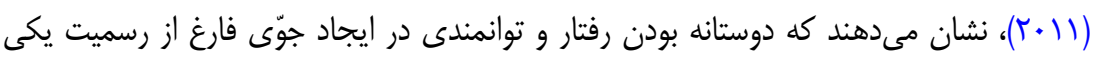

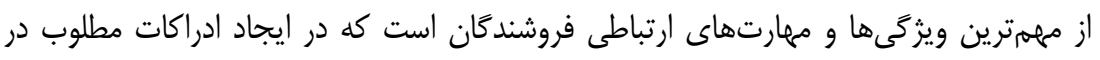

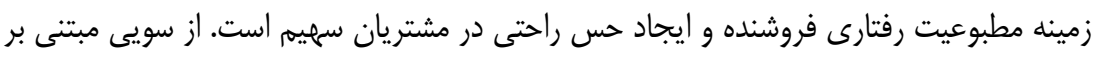

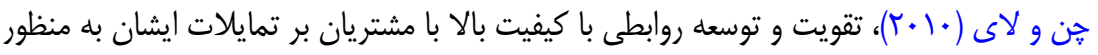

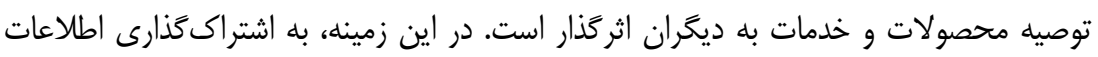

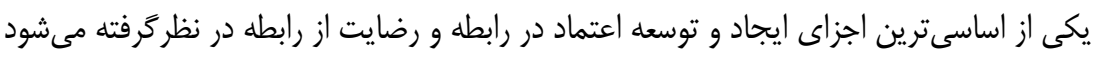

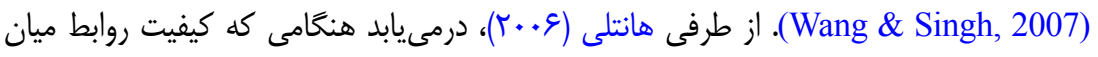

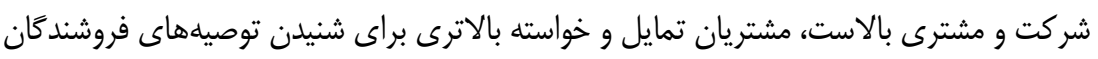

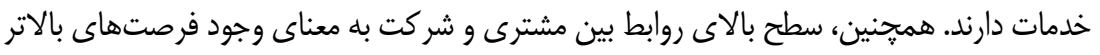

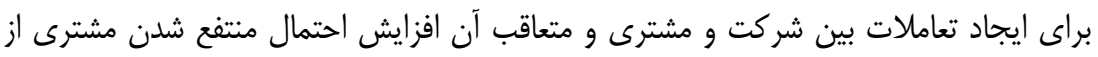

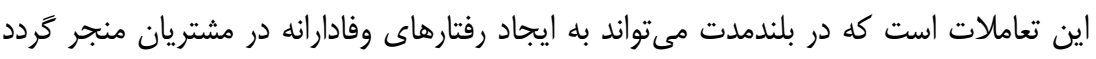

(Macintosh, 2007) في فروشنده بر وفادارى مشتريان دارد. في فروش رابطهمند بر وفادارى مشتريان دارد.

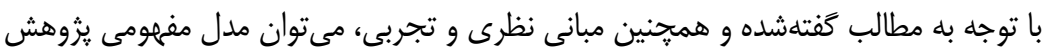
را به صورت شكل (1) بيان كرد. 


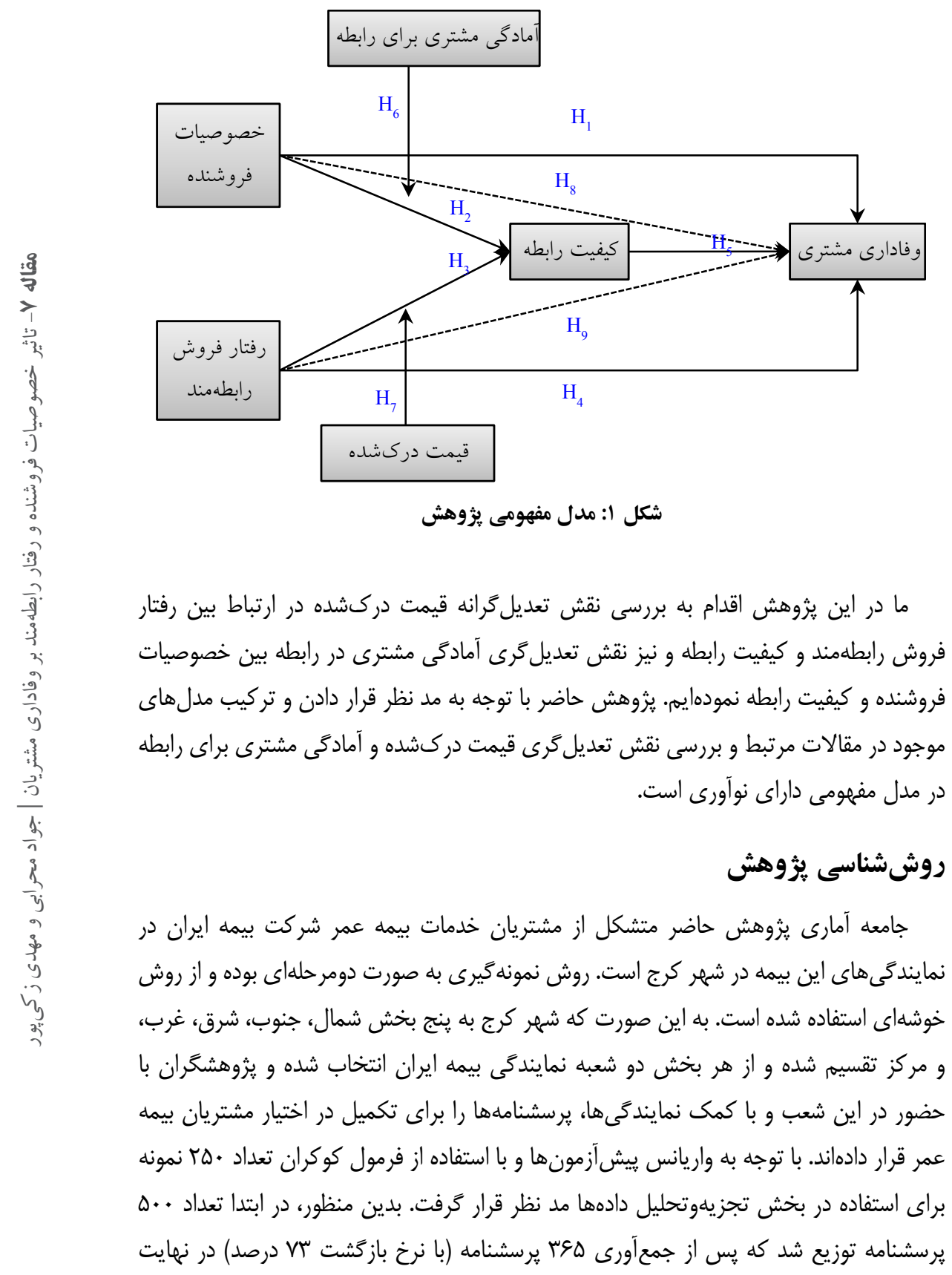


تعداد سم يرسشنامه انتخاب و وارد فرايند يزوهش گرديد. نياز به اشاره است در مرحله انتخاب

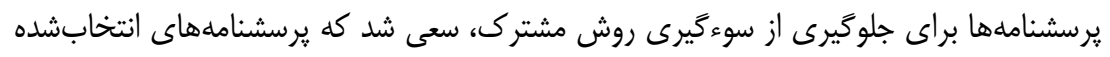

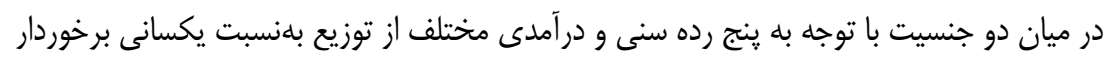
باشند. مدت زمان جمع آورى دادهها هأ روز بود.

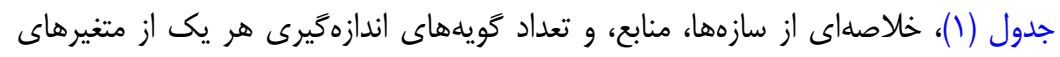

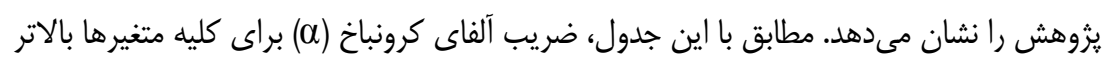

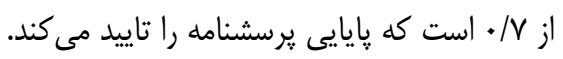

جدول 1: سنجش عملياتى و پايايى متغيرهاى يزوهش

\begin{tabular}{|c|c|c|c|c|}
\hline$\alpha$ & منابع & ل إرسشها & ابعاد اد & متغيرها \\
\hline$\cdot / \Lambda G Y$ & 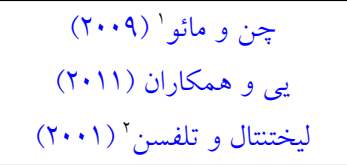 & $\begin{array}{l}1-r \\
r-q \\
v-q\end{array}$ & 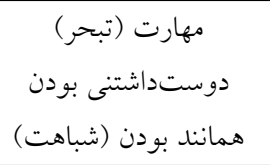 & خروشندهات \\
\hline$\cdot / V Q \Lambda$ & 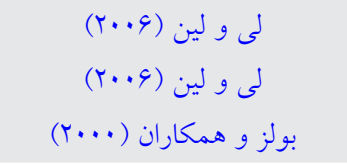 & $\begin{array}{l}1 \cdot-1 r \\
\mid r-19 \\
|V-r|\end{array}$ & 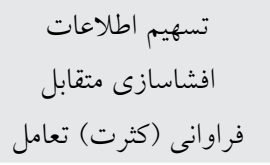 & رفتار فروشه رابطد \\
\hline - NTY & 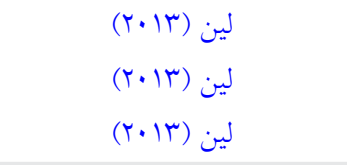 & $\begin{array}{l}r t-t g \\
r V-r . \\
r-r y\end{array}$ & صداقت & كيفيت رابطه \\
\hline$\cdot / \vee 90$ & يوشنه و واسكز - ياراكا (Y.19) & ro-rı & \multicolumn{2}{|c|}{ وفادارى مشترى } \\
\hline •/AMt & ليختتال و تلفسن (1. (Y) & $r q-4 \mid$ & \multicolumn{2}{|c|}{ قيمت دركشده } \\
\hline$\cdot / \Lambda<q$ & لى و لين (Y..4) & KT-YQ & \multicolumn{2}{|c|}{ آمادكى مشترى براى رابطه } \\
\hline
\end{tabular}

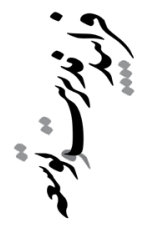

جدول (ץ)، نتايج آمار توصيفى متغيرهاى ثروهش را نشان مىدهد. در اين جدول شاخصهاى

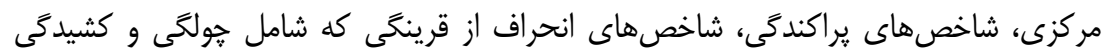

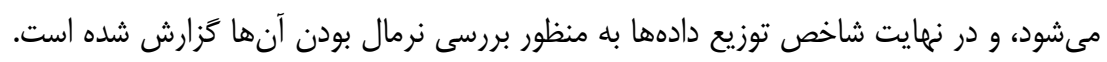

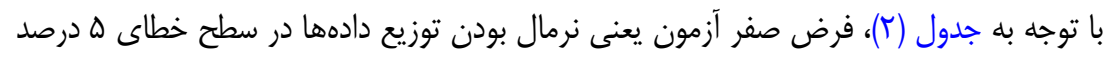

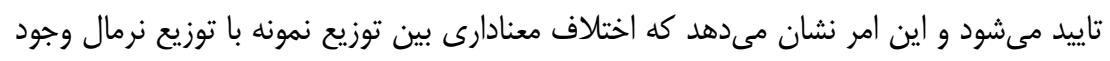

\section{Chen \& Mau}

2. Lichtenthal \& Tellefsen 
ندارد. با توجه به نرمال بودن دادهها از نرمافزار AMOS براى مدلسازى معادلات ساختارى'

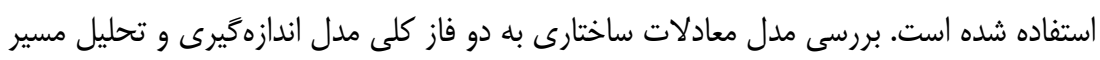

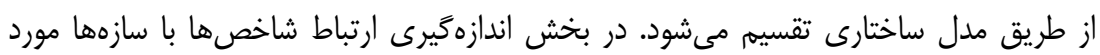

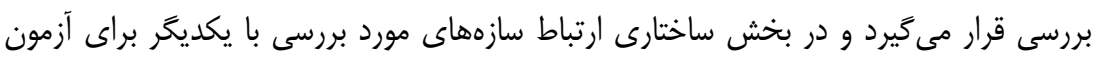

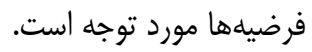

\begin{tabular}{|c|c|c|c|c|c|c|c|}
\hline \multicolumn{2}{|c|}{ شاخص توزيع } & \multicolumn{2}{|c|}{ شاخص هاى انحر اف } & \multicolumn{2}{|c|}{ شاخص هاى } & \multirow{2}{*}{ شاخص هزى ميان } & \multirow[t]{2}{*}{ متغير } \\
\hline معنادارى & مقدار Z & كثيدگى & جولخى & واريانس & انحر اف & & \\
\hline •/NAr & $\cdot / \cdot Y I$ & $\cdot / \cdot V V$ &.$/ 4 \mu$. & $\cdot / 790$ & - /OFY & r/994 & خصوصيات فروشنده \\
\hline$\cdot / 901$ & 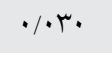 &.$/ 148$ & ./MI & D MYT &.$/ 949$ & r/QRT & رفتار فروش رابطهمند \\
\hline$\cdot 1 \cdot 199$ & $\cdot / \cdot Y Y$ & - /ADS & $\cdot \mu \wedge \vee$ &.$/ T 94$ & - /OFY & r/949 & كيفيت رابطه \\
\hline.$/ 140$ & $\cdot / \cdot r q$ & $-\cdot / T T \Delta$ &.$- / 110$ & $\cdot / \Delta V r$ & $\cdot / V Q V$ & r/949 & وفادارى مشترى \\
\hline .1 .91 & . & $-\cdot / T \Delta G$ & $\cdot / \pi 19$ & . $/ \Delta r^{\prime}$. & $\cdot / V Y V$ & $r / 91$. & قيمت دركشده \\
\hline D TKY & . & $\cdot / F V Y$ & $.1 .9 \mathrm{~V}$ & $\cdot / \mu<q$ &.$/ 09$ & $r / 9 V 4$ & آمادكى براى رابطه \\
\hline
\end{tabular}

\section{برازش مدلهاى اندازهكيرى}

براى بررسى برازش مدلهاى اندازهگيرى از سه معيار קايايى شاخص (يايايى تركيبى' و

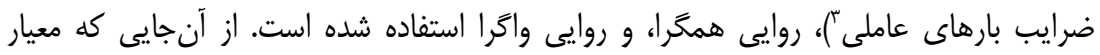

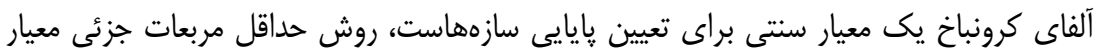

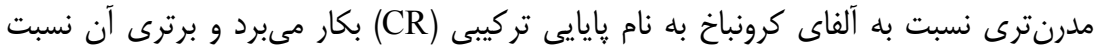

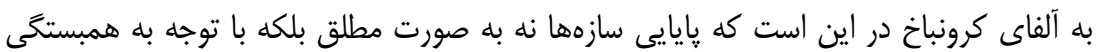

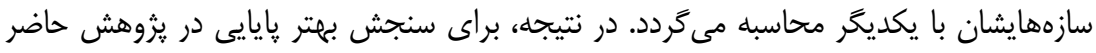

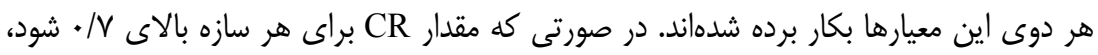

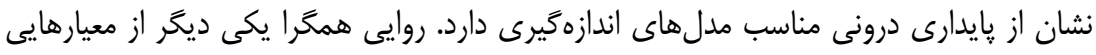

1. Structural Equation Model (SEM)

2. Composite Reliability (CR)

3. Factor Loadings 
است كه براى برازش مدلهاى اندازهيرى بكار مىرود. در اين خصوص فورنل و لاركر' (1911)،

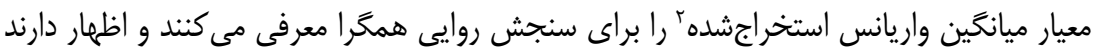

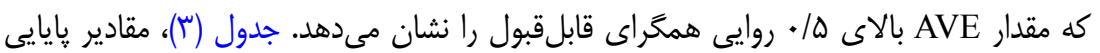
تركيبى و ضرايب بارهاى عاملى را براى سنجش پايايى شاخصهاى اندازهيرى و ضريب روايى

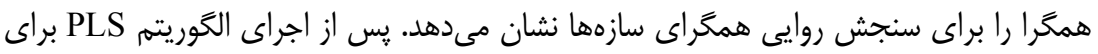

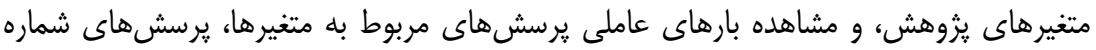

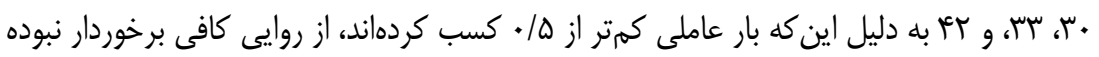
و در روند تحليل باقى نماندهاند (Hulland, 1999; Rivard \& Huff, 1988).

جدول ": بار عاملى، پايايى تر كيبى، و روايى همكراى متغيرهاى ثيزوهش

\begin{tabular}{|c|c|c|c|}
\hline عاملى & تر يايايى & همخرا & سازه و گويه \\
\hline & $\cdot / A V V$ & $\cdot / 0199$ & مهارت (تبحر) \\
\hline
\end{tabular}

\begin{tabular}{|c|c|}
\hline .1994 & فروشندگان بيمه عمر ايران از دانش تخصصى بالايى در اين زمينه برخوردار هستند. \\
\hline$\cdot / 0 \cdot r$ & فروشندكان بيمه عمر ايران به صورت حرفهاى بيمه عمر را معرفى مى كنند. \\
\hline .1949 & فروشندكان بيمه عمر ايران توانايى ياسخ به سوالات در زمينه بيمه عمر را دارند. \\
\hline & $\cdot / A Y \Lambda \quad \cdot / 91 \mathrm{~V}$ \\
\hline
\end{tabular}

\begin{tabular}{|c|c|}
\hline •NVIT & فروشند كان بيمه عمر ايران رفتار مهربانانهاى با مشتريان دارند. \\
\hline$\cdot / \Delta r$ & فروشندگان بيمه عمر ايران مودب هستند. \\
\hline$\cdot / v \cdot r$ & فروشندكان بيمه عمر ايران با مشتريان با خوشرويى برخورد مى كنند. \\
\hline$\cdot / \Lambda T Q$ & همانند بودن (شباهت) 191r \\
\hline
\end{tabular}

\begin{tabular}{|c|c|}
\hline .1999 & بيمه عمر ايران با سبك زندكى من مطابقت دارد. \\
\hline$\cdot / \mathrm{Mr}$ & بيمه عمر ايران با سطح اجتماعى من همتراز است. \\
\hline$\cdot / \mathrm{M} \Delta$ & با توجه به سطح تحصيلات من، بيمه عمر ايران قابلفهم است. \\
\hline$\cdot$ NYA & تسهيم اطلاعات \\
\hline
\end{tabular}

\begin{tabular}{|c|c|}
\hline$\cdot / N Y$ & اطلاعاتى كه فروشندگان بيمه عمر ايران در اختيارم مى گذارند بسيار دقيق است. \\
\hline$\cdot / V 9 \Lambda$ & اطلاعاتى كه درباره بيمه عمر در اختيارم مى گذارند، بسيار كامل است. \\
\hline$\cdot$ • VAr & اطلاعاتى كه در زمينه بيمه عمر ايران در اختيارم گذاشته مىشود، قابل اعتماد است. \\
\hline
\end{tabular}

1. Fornell \& Larcker

2. Average Variance Extracted (AVE) 
ادامه جدول "ّ: بار عاملى، پايايى تركيبى، و روايع همكر اى متغيرهاى يزوهش

\begin{tabular}{|c|c|c|}
\hline عاملى & تر يايايى & 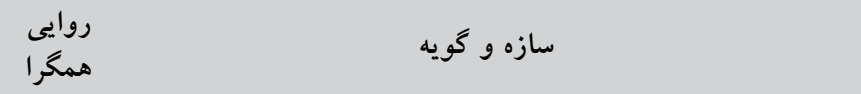 \\
\hline & $\cdot / \wedge Q \vee$ & 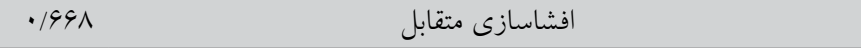 \\
\hline$\cdot / \wedge \cdot V$ & & بيمه ايران مشتريان خود را در جريان وضعيت مالى شركت قرار مىدهد. \\
\hline .1994 & & بيمه ايران مشتريان خود را در جريان اهداف مالى شركت قرار مىدهد. \\
\hline$\cdot / 94 \cdot$ & & بيمه ايران مشتريان خود را در جريان رشد مالى شركت قرار مىدهد. \\
\hline$\cdot / 0 \cdot r$ & & بيمه ايران در مورد ارزشها و راهبردهاى خود با مشتريان تعامل دارد. \\
\hline & $\cdot / \sqrt{94}$ & فراو انى (كثرت) تعامل \\
\hline • NAV & & فروشند كان بيمه عمر ايران مرتب با من در تماس هستند. \\
\hline • N9Q & & فروشند كان بيمه عمر ايران در مورد تغييرات احتمالى در بيمه عمر با من در ارتباط هستند. \\
\hline - NQY & & فروشندكان بيمه عمر ايران براى بررسى نيازهاى بيمهاى با من در ارتباط هستند. \\
\hline • NVG & & بيمه ايران هديهاى را براى سالروز تولد مشتريان خود در نظر مى گيرد. \\
\hline$\cdot \mathrm{V}^{\top} \Lambda$ & & بيمه ايران براى دادن اطلاعات در مورد بيمه عمر با مشتريان خود در تعامل است. \\
\hline & •/AIT & رضايت \\
\hline$\cdot$ - NAY & & حس خوبى در تعامل با فروشندگان بيمه عمر ايران دارم. \\
\hline • NQT & & از ارائه خدمات حرفهاى فروشند كان بيمه عمر ايران حس رضايت دارم. \\
\hline$\cdot / \mathrm{N} \Delta$ & & از كيفيت خدمات فروشندكان بيمه عمر ايران احساس رضايت مى كنم. \\
\hline$\cdot / A r r$ & & از ارتباطى كه با فروشندگان بيمه عمر ايران دارم، راضى هستم. \\
\hline$\cdot / \Lambda \mathrm{HV}$ & & بهور كلى از خدمات بيمه ايران رضايت دارم. \\
\hline & $\cdot$ - VAY & 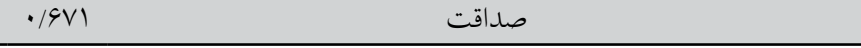 \\
\hline$\cdot / 110$ & & فروشندكان بيمه عمر ايران رفتارى دوستانه دارند. \\
\hline$\cdot / A r$ & & فروشندگان بيمه عمر ايران در كارشان تقلب نمى كنند. \\
\hline$\cdot 1940$ & & فروشندكان بيمه عمر اير ان در حل مشكلات مشتريان خود صادقانه برخورد مى كنند. \\
\hline & $\cdot / 119$ & $\cdot / 9 K T$ \\
\hline$\cdot / \Delta r V$ & & متعهد مى شوم كه با بيمه ايران ارتباط طولانىمدت داشته باشم. \\
\hline$\cdot 1994$ & داشته باشم. & حتى اخر جايكزينى براى خدمات بيمهاى داشته باشم، قصد دارم ارتباطم را با بيمه عمر ، \\
\hline$\cdot 19 K T$ & & ميان شركت بيمه ايران و مشتريانش تعهد و وفادارى وجود دارد. \\
\hline & -NG9 & وفادارى مشترى \\
\hline • NAT & & مايلم شركت بيمه ايران را به ديخران توصيه كنم. \\
\hline$\cdot / \Lambda \mu^{4}$ & & استفاده از خدمات بيمه ايران را ادامه خواهم داد. \\
\hline$\cdot / \Lambda \mathrm{V}$ & & به نظر من بهترين انتخاب در ميان شركتهاى بيمه، بيمه ايران است. \\
\hline •NMI & & از ساير خدمات بيمهاى اين شركت نيز استفاده خواهم كرد. \\
\hline
\end{tabular}


ادامه جدول بّ: بار عاملى، پايايى تركيبى، و روايى همغراى متغيرهاى ثخوهش

\begin{tabular}{|c|c|c|c|}
\hline عاملى & تر يايايى & همخرا & 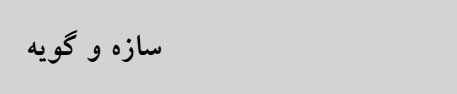 \\
\hline & $\cdot / \Lambda F V$ & $\cdot 1991$ & قيمت دركشده \\
\hline$\cdot /$ MA & \multicolumn{3}{|c|}{ نرخ خدمات بيمهاى در بيمه ايران از ساير شركتهاى بيمه يايينتر است. } \\
\hline$\cdot / \wedge 94$ & \multicolumn{3}{|c|}{ توسط نرخ خدمات بيمهاى در بيمه ايران در مقايسه بانرخ خدمات در بازار بيمه يايينتر است. } \\
\hline$\cdot / 911$ & \multicolumn{3}{|c|}{ هزينههاى خحمات بيمه در بيمه ايران پايينتر است. } \\
\hline & $\cdot / \mathrm{Q} \wedge$ & .1949 & آمادگى مشترى براى ر \\
\hline$\cdot / \Lambda Q V$ & & & مىخواهم با بيمه ايران بلهور مـ \\
\hline$\cdot / \Lambda 9 V$ & & & مى خواهم به عنوان يك مشترى ارتباط ٍِا \\
\hline$\cdot / \mathrm{N} / \mathrm{r}$ & & & مىخو اهم با فروشندكان بيمه عمر ايران \\
\hline
\end{tabular}

براى بررسى روايى واگراى سازههاى اندازهيرى از روش فورنل و لاركر استفاده شده است. در جدول

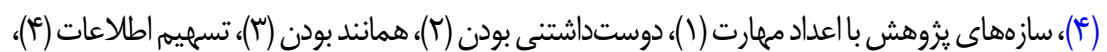

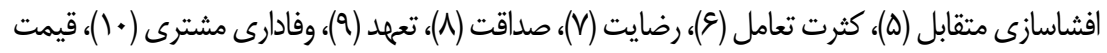

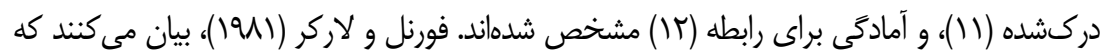

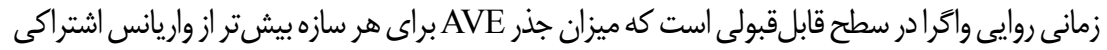
بين آن سازه و سازههاى ديگر در مدل باشد. بررسى اين مدل توسط يك ماتريس به صورت جدول (أ) انجام مىيذيرد. همان طور كه مشاهده مىشود، خانههاى اين جدول حاوى مقادير ضر ايب همبستخى بين سازهها و جذر مقادير AVE مربوط به هر سازه است. اعداد مندرج در قطر اصلى جدول از مقادير زيرين خود بيشتر است. بنابراين، مدل هاى اندازهگيرى از روايى واگراى قابل قبولى برخوردار هستند.

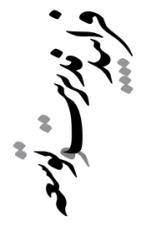

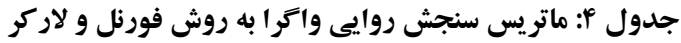

\begin{tabular}{|c|c|c|c|c|c|c|c|c|c|c|c|c|}
\hline (IY) & (11) & (1.) & (9) & (^) & (V) & (9) & $(\Delta)$ & $(\boldsymbol{f})$ & $(\boldsymbol{r})$ & $(Y)$ & (1) & سازه \\
\hline & & & & & & & & & & & - /VAV & (1) \\
\hline & & & & & & & & & & $\cdot / V \wedge \Delta$ & - NDS & (Y) \\
\hline & & & & & & & & & - JAY & • N W & $\cdot / N r^{\mu}$ & $(\boldsymbol{Y})$ \\
\hline & & & & & & & & $\cdot / N V$. & .1990 & ז'ות . & . /NTK & $(\boldsymbol{\Psi})$ \\
\hline & & & & & & & $\cdot / \mathrm{NIV}$ & . /N19 & $\cdot / 90 \mathrm{~V}$ & . /VYa & $\cdot / N{ }^{m}$ & $(\Delta)$ \\
\hline & & & & & & - /VA4 & . $190 \mathrm{r}$ & $\cdot / V^{4} \mid$ & $\cdot / V^{4} \mid$ & . NYks & $.19 \mathrm{Vr}$ & (9) \\
\hline
\end{tabular}




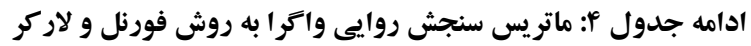

\begin{tabular}{|c|c|c|c|c|c|c|c|c|c|c|c|c|}
\hline (IY) & (11) & (1.) & (9) & (^) & (v) & (9) & (Q) & $(f)$ & (r) & (Y) & (1) & سازه \\
\hline & & & & & . NGY & - MEY & $.199 \mathrm{~V}$ & $\cdot N \& \Delta$ & .1911 & $.191 \mathrm{~V}$ & - Igky & (V) \\
\hline & & & & - $/ 119$ & .1949 & $\cdot / 219$ & $\cdot / N \mu^{K}$ & - $/ N Q Q$ & - /VQr & $\cdot / N T I$ &.$/ 90$. & $(\wedge)$ \\
\hline & & & - NAM & $\cdot / v \cdot q$ & $\cdot 1901$ & $\cdot / 900$ &.$/ 91$. & . NKF & - / V 99 &.$/ 9 \mathrm{VT}$ & $\cdot / V \backslash \Lambda$ & (9) \\
\hline & & $\cdot / V V r$ & $\cdot / \mathrm{NVV}$ & $\cdot / V T V$ & $\cdot / V Q 1$ & - N $k q$ & $\cdot / V Q \Lambda$ & $.19 \cdot 0$ & .1901 & $\cdot / 911$ & .1901 & $(1 \cdot)$ \\
\hline & •/AIV & $.19 V \mu$ & - NYY &.$/ 219$ & . NT. & . NAT & $\cdot / v \cdot V$ & $\cdot / N 1 Q$ & . $/ 941$ &.$/ 941$ &.$/ 940$ & (11) \\
\hline$\cdot / 1 \cdot 0$ & $\cdot / \mathrm{VAl}$ & - NIV & $\cdot N \cdot \Delta$ & $\cdot / \Lambda \cdot r$ & .1019 & .1991 &.$/ 9 \Lambda K^{4}$ & - $/ \mathrm{V} 90$ & $\cdot / v \cdot q$ & - $/ \mathrm{V} Q 0$ & $\cdot / V T V$ & $(I Y)$ \\
\hline
\end{tabular}

\section{بروسى برازش مدل ساختارى ثئوهش}

مقدار R-Square يا R² بهدستآمده در مدل ساختارى در حالت PLS نشان از ميزان تبيين و

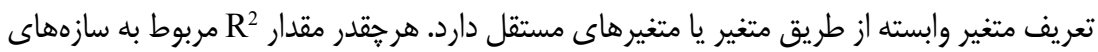

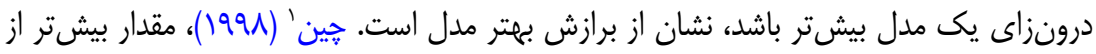
VVI • • را به عنوان يك ملاكى براى برازش قوى بخش ساختارى مدل معرفى كردهاند. اين مقدار

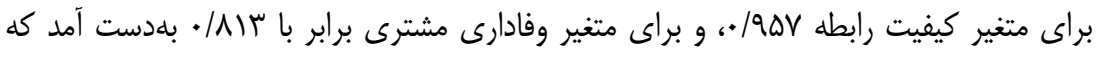
نشان از برازش قوى بخش ساختارى مدل به وسيله معيار R دارد. شاخص كلى برازشr (GOF)

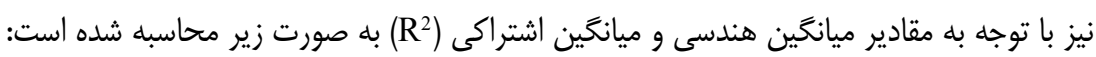
GOF $=\sqrt{\overline{\text { Communalitıes }} \times \overline{R^{2}}}$

$\overline{\text { Communalıtıes }}=(0.431+0.534+0.551+0.81+0.743+0.647) / 6=0.619$ براى محاسبه مقدار آنها را محاسبه نمود. ميزان $G O F=\sqrt{0.619 * 0.885}=0.741$

مقدار |ع|V|• نشان از برازش مناسب مدل كلى يثوهش دارد.

1. Chin

2. Goodness of Fit 


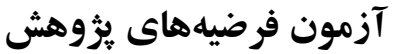

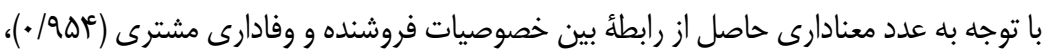
فرضيه H تاييد نشده است. يعنى خصوصيات فروشنده اثر معنادارى بر وفادارى مشترى ندارد. با توجه به عدد معنادارى حاصل از رابطأ بين خصوصيات فروشنده و كيفيت رابطه با مشترى

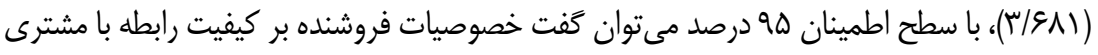

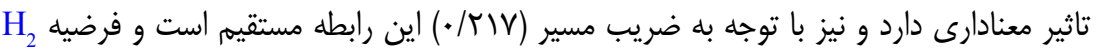

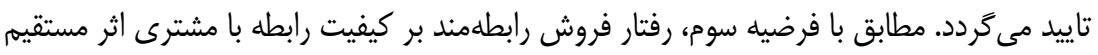

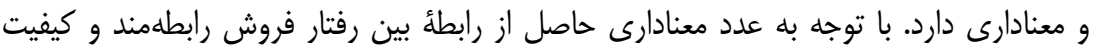

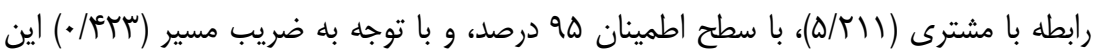
رابطه مستقيم است و فرضيه H تاييد مى گردد. با توجه به عدد معنادارى حاصل از رابطهُ بين رفتار

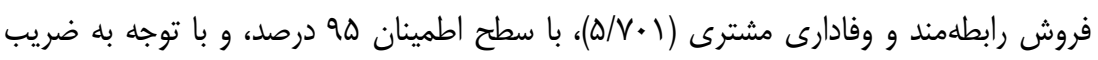

$$
\text { مسير (•0ه/•)، فرضيه }
$$

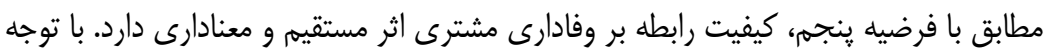

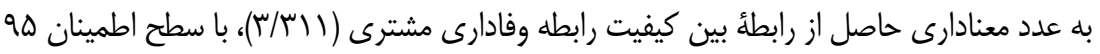

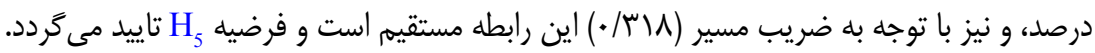

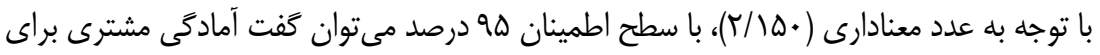
برقرارى رابطه، نقش تعديل كننده معنادارى در رابطه بين خصوصيات فروشنده و كيفيت رابطه با

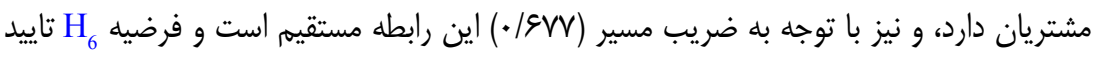

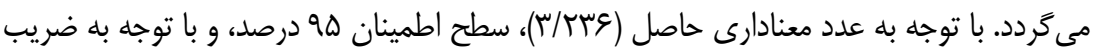

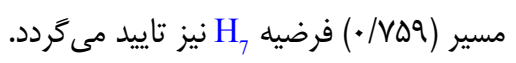

مطابق با فرضيه هشتم، كيفيت رابطه مشترى با سازمان نقش ميانجى گرى مستقيم و معنادارى

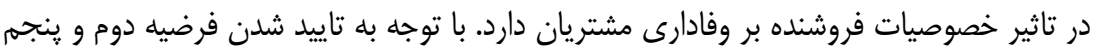

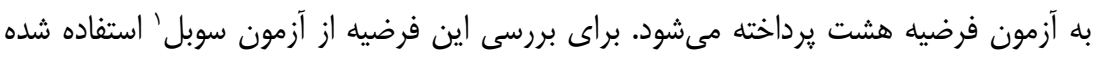

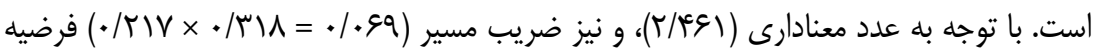
$Z_{8}=\frac{3.681 \times 3.311}{\sqrt{5.211^{2}+3.311^{2}}}=2.461$

H ت تاييد شده است.

1. Sobel 
همجنين، با توجه به تاييد شدن فرضيه سه و ونج به آزمون فرضيه نهم يرداخته مىشود. با

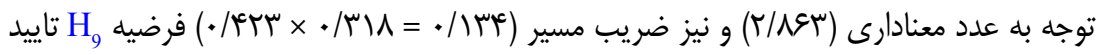
شده است. جدول (ه)، خلاصهاى نتايج آزمون فرضيهها را نشان مىدهد.

جدول ه: بررسى فرضيههاى بزوهش

\begin{tabular}{|c|c|c|c|c|c|c|c|}
\hline نتيجه & معنادارى & $\boldsymbol{\beta}$ & & 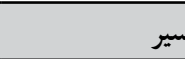 & & & فرضيه \\
\hline رد & $\cdot / 9 \Delta Y$ &.$- / \cdot$ rs & وفادارى مشترى & $<<<<$ & & & $\mathrm{H}_{1}$ \\
\hline تاييد & $r / 9 \wedge 1$ & $\cdot / Y \mid V$ & (1) & $<<<<$ & & & $\mathrm{H}_{2}$ \\
\hline تاييد & $Q / Y \backslash 1$ & DTt & يقيت رابطه & $<<<<$ & فتا, فو ش رابطهمند & & $\mathrm{H}_{3}$ \\
\hline تاييد & $0 / V \cdot 1$ & $\cdot / 90$ & & $<<<<$ & رستر مروس رابطهمس & & $\mathrm{H}_{4}$ \\
\hline تاييد & T/M & 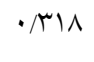 & & $<<<<$ & كيفيت رابطه & & $\mathrm{H}_{5}$ \\
\hline تاييد & $r / 10$. & $\cdot 19 \mathrm{VV}$ & كيفيت رابطه & قيمت دركشده & رفتار فروش رابطهمند & $\begin{array}{l}2 \\
3\end{array}$ & $\mathrm{H}_{6}$ \\
\hline تاييد & $r / T \mu_{G}$ & $\cdot / V Q 9$ & & آمادگى مشترى & خصوصيات فروشنده & & $\mathrm{H}_{7}$ \\
\hline تاييد & $r / 4 \& 1$ & .1 .99 & & كفتت إط & خصوصيات فروشنده & & $\mathrm{H}_{8}$ \\
\hline تاييد & T/AGT & $\cdot / M \mu^{\prime}$ & & "ي "ي كن. & لي رفتتار فروش رابطهمند & & $\mathrm{H}_{9}$ \\
\hline
\end{tabular}

\section{بحث و نتيجه كيرى}

هدف يزوهش حاضر بررسى تاثير ويزگى هاى فروشنده و تعاملات بين فروشنده ـ مشترى بر كيفيت روابط تعاملى و وفادارسازى مشتريان در صنعت بيمه است. نتايج مطالعه حاكى از تعديلگرى متغيرهاى آمادگى مشترى براى رابطه و قيمت دركشده در تاثير متغيرهاى مستقل

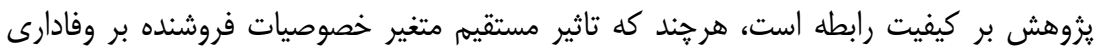
مشترى تاييد نشده است. تاييد نشدن فرضيه اول مبنى بر نبود اثر مستقيم خصوصيات فروشنده بر وفادارى مشترى مىتواند گوياى وجود عوامل ديخر ناشناختهاى باشد كه مىتواند وفادارى مشترى را تحت تاثير قرار دهد، از قبيل رفتار فروش رابطهمند كه در اين يثوهش اثر مستقيم و معنادارى بر وفادارى مشترى داشته است. بنابراين، مىتوان استدلال كرد كه رفتار فروش در مقايسه با خصوصيات شخصى فروشنده تاثير بيشترى بر وفادارى مشتريان خواهد داشت. در خصوص تاثير

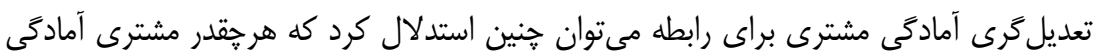


بيشترى براى رابطه داشته باشد خصوصيات ايدهآل فروشنده تاثير كذارى بيشترى بر كيفيت

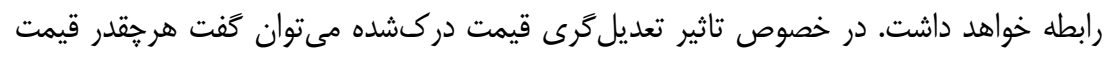

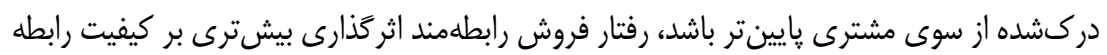
خواهد داشت. براى بررسى نقش ميانجى گرى كيفيت رابطه در مسير تاثير خصوصيات فروشنده بر وفادارى

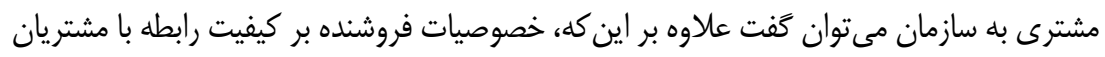

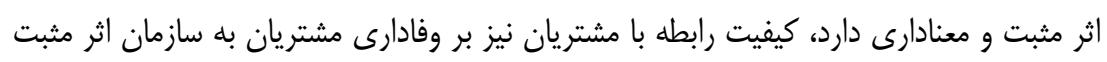

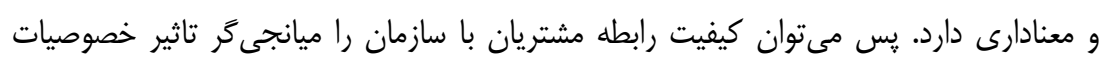

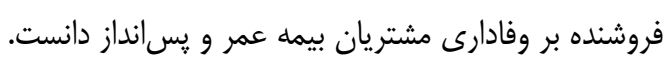

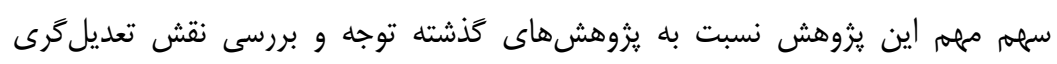

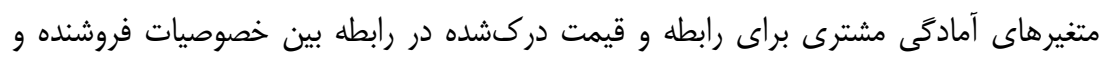

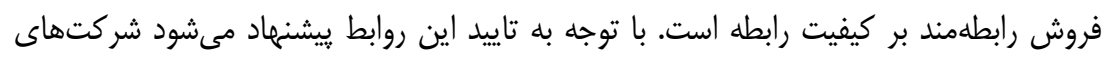

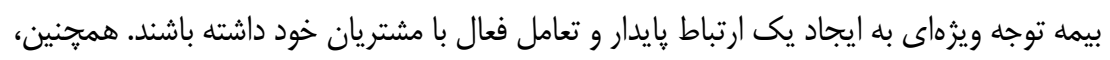

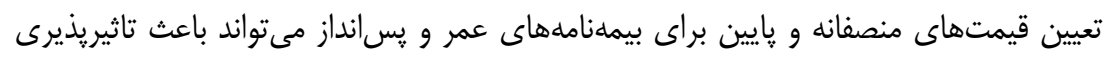

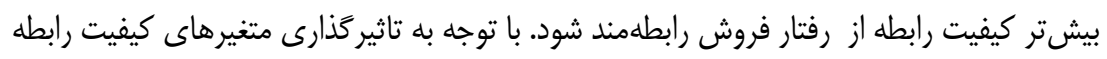

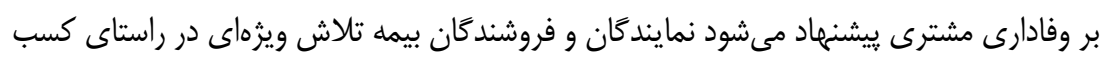

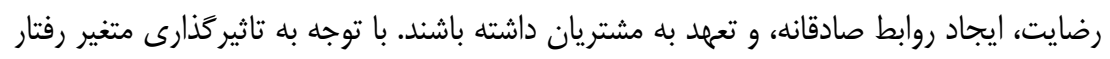

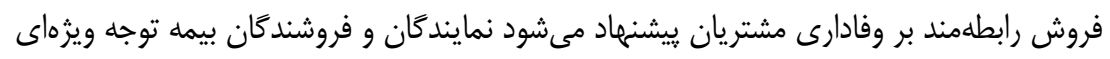

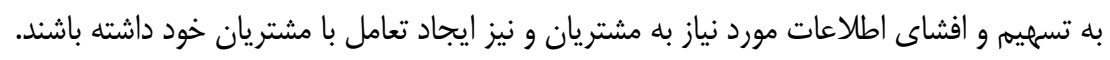

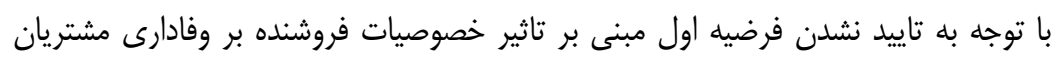

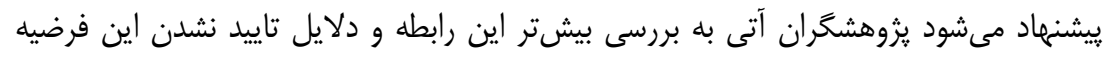

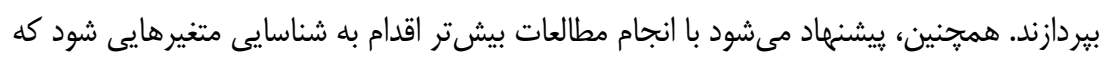
مىتواند در اين رابطه نقش تعديل

\section{اظهاريه}

نويسندًان از حمايتهاى معنوى همكاران، داوران ناشناس، و ويراستار علمى نشريه فرايند

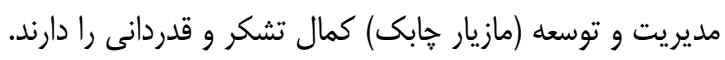


Ainiyah, S. M., Nelloh, L. A. M., \& Sjahrifa, C. (2020). Life Insurance Customer Loyalty. Paper Presented at the the International Conference on Business and Management Research (ICBMR 2020). https://doi.org/10.2991/aebmr.k.201222.012

Ansari, A., \& Riasi, A. (2016). Modelling and Evaluating Customer Loyalty Using Neural Networks: Evidence from Startup Insurance Companies. Future Business Journal, 2(1), 15-30. https://doi.org/10.1016/j.fbj.2016.04.001

Boles, J. S., Johnson, J. T., \& Barksdale Jr, H. C. (2000). How Salespeople Build Quality Relationships: A Replication and Extension. Journal of Business Research, 48(1), 75-81. https://doi.org/10.1016/S0148-2963(98)00078-2

Chen, M. S., \& Lai, G. C. (2010). Distribution Systems, Loyalty and Performance. International Journal of Retail \& Distribution Management, 38(9), 698-718. https://doi.org/10.1108/09590551011062448

Chen, M.-F., \& Mau, L.-H. (2009). The Impacts of Ethical Sales Behaviour on Customer Loyalty in the Life Insurance Industry. The Service Industries Journal, 29(1), 59-74. https://doi.org/10.1080/02642060802116339

Chen, Q., Goldstein, I., \& Jiang, W. (2007). Price Informativeness and Investment Sensitivity to Stock Price. The Review of Financial Studies, 20(3), 619-650. https://doi.org/10.1093/rfs/hhl024

Chen, Z. X., Shi, Y., \& Dong, D. H. (2008). An Empirical Study of Relationship Quality in a Service Setting: A Chinese Case. Marketing Intelligence \& Planning, 26(1), 11-25. https://doi.org/10.1108/02634500810847129

Chin, W. W. (1998). Commentary: Issues and Opinion on Structural Equation Modeling. MIS Quarterly 22(1), vii-xvi.

Chiu, H.-C., Hsieh, Y.-C., Kao, Y.-H., \& Lee, M. (2007). The Determinants of Email Receivers' Disseminating Behaviors on the Internet. Journal of Advertising Research, 47(4), 524-534.

Choi, Y. G., \& Hyun, S. S. (2017). Relationships between Brand Experiences, Personality Traits, Prestige, Relationship Quality, and Loyalty: An Empirical Analysis of Coffeehouse Brands. International Journal of Contemporary Hospitality Management, 29(4), 1185-1202. https://doi.org/10.1108/IJCHM-11-2014-0601

Dominique-Ferreira, S. (2018). The Key Role Played by Intermediaries in the Retail Insurance Distribution. International Journal of Retail \& Distribution Management, 46(11/12), 1170-1192. 
https://doi.org/10.1108/IJRDM-10-2017-0234

Fornell, C., \& Larcker, D. F. (1981). Evaluating Structural Equation Models with Unobservable Variables and Measurement Error. Journal of Marketing Research, 18(1), 39-50. https://doi.org/10.1177/002224378101800104

Gharepasha, A., Aali, S., Bafandeh Zendeh, A., \& Iranzadeh, S. (2018). Customer's Loyalty to Online Banking Services. Quarterly Journal for Management and Development Process, 31(3), 151-180. http://jmdp.ir/article-1-3157-fa.html

Guenzi, P., \& Georges, L. (2010). Interpersonal Trust in Commercial Relationships: Antecedents and Consequences of Customer Trust in the Salesperson. European Journal of Marketing, 44(1/2), 114-138. https://doi.org/10.1108/03090561011008637

Hulland, J. (1999). Use of Partial Least Squares (PLS) in Strategic Management Research: A Review of Four Recent Studies. Strategic Management Journal, 20(2), 195-204. https://doi.org/10.1002/(SICI)1097-0266

Huntley, J. K. (2006). Conceptualization and Measurement of Relationship Quality: Linking Relationship Quality to Actual Sales and Recommendation Intention. Industrial Marketing Management, 35(6), 703-714. https://doi.org/10.1016/j.indmarman.2005.05.011

Konjkav Monfared, A. R., Rezaei Dolatabadi, H., \& Mahmoodi Meimand, M. (2015). Analyzing the Moderating Effect of Hedonic Value on Process of Developing Brand Loyalty. Quarterly Journal for Management and Development Process, 28(3), 157-175. http://jmdp.ir/article-1-1586-fa.html Larson, R. K., \& Street, D. L. (2004). Convergence with IFRS in an Expanding Europe: Progress and Obstacles Identified by Large Accounting Firms' Survey. Journal of International Accounting, Auditing and Taxation, 13(2), 89-119. https://doi.org/10.1016/j.intaccaudtax.2004.09.002

Lee, A. H., Kang, H.-Y., Hsu, C.-F., \& Hung, H.-C. (2009). A Green Supplier Selection Model for High-Tech Industry. Expert Systems with Applications, 36(4), 7917-7927. https://doi.org/10.1016/j.eswa.2008.11.052

Li, S., \& Lin, B. (2006). Accessing Information Sharing and Information Quality in Supply Chain Management. Decision Support Systems, 42(3), 1641-1656. https://doi.org/10.1016/j.dss.2006.02.011

Lichtenthal, J. D., \& Tellefsen, T. (2001). Toward a Theory of Business BuyerSeller Similarity. Journal of Personal Selling \& Sales Management, 21(1), 1-14. Lin, S.-Y. (2013). The Influence of Relational Selling Behavior on Relationship Quality: The Moderating Effect of Perceived Price and Customers' Relationship Proneness. Journal of Relationship Marketing, 12(3), 204222. https://doi.org/10.1080/15332667.2013.816931

Macintosh, G. (2007). Customer Orientation, Relationship Quality, and 
Relational Benefits to the Firm. Journal of Services Marketing, 21(3), 150159. https://doi.org/10.1108/08876040710746516

Ndubisi, N. O. (2007). Relationship Marketing and Customer Loyalty. Marketing Intelligence \& Planning, 25(1), 98-106. https://doi.org/10.1108/02634500710722425

Poushneh, A., \& Vasquez-Parraga, A. Z. (2019). Emotional Bonds with Technology: The Impact of Customer Readiness on Upgrade Intention, Brand Loyalty, and Affective Commitment through Mediation Impact of CustomerValue. Journal of Theoretical and Applied Electronic Commerce Research, 14(2), 90-105. https://doi.org/10.4067/S0718-18762019000200108

Rivard, S., \& Huff, S. L. (1988). Factors of Success for EndUser Computing. Communications of the ACM, 31(5), 552-561. https://doi.org/10.1145/42411.42418

Solomon, M. R., Surprenant, C., Czepiel, J. A., \& Gutman, E. G. (1985). A Role Theory Perspective on Dyadic Interactions: The Service Encounter. Journal of Marketing, 49(1), 99-111. https://doi.org/10.1177/002224298504900110

Tai, Y.-M., Ho, C.-F., \& Wu, W.-H. (2010). The Performance Impact of Implementing Web-Based E-Procurement Systems. International Journal of Production Research, 48(18), 5397-5414. https://doi.org/10.1080/00207540903117915

Wang, Y., \& Singh, M. P. (2007). Formal Trust Model for Multiagent Systems. Paper Presented at the IJCAI, 1551-1556.

Yi, Y., Nataraajan, R., \& Gong, T. (2011). Customer Participation and Citizenship Behavioral Influences on Employee Performance, Satisfaction, Commitment, and Turnover Intention. Journal of Business Research, 64(1), 87-95. https://doi.org/10.1016/j.jbusres.2009.12.007

Yu, T.-W., \& Tseng, L.-M. (2016). The Role of Salespeople in Developing Life Insurance Customer Loyalty. International Journal of Retail \& Distribution Management, 44(1), 22-37. https://doi.org/10.1108/IJRDM-06-2014-0074 